\title{
昭和55年度 春季全国大会シンポジウム報告
}

\section{原子カプラントにおける溶接技術*}

\author{
栗山良山員** \\ Welding Technology for Nuclear Power Plant*
}

by Yoshikazu Kuriyama**

昭和55年 4 月 8 日, 標記の主題で, 座長栗山（IHI) の司会により，5つの基临報告と活発な討諭がなされ た.

本シンポジゥムの基調暼演は

1. 原子炉用機器への肉盛溶接法, 有井, 竹中（東 芝), 条 (IHI).

2. オーステナイト系ステンレス鋼管の多層円淍突合 女溶接一の水冷法の適用とその残留応力, 上曰, 中長 (阪大)，清水 (日立)，笠井 (阪大，大学院）。

3. ステンレス鋼管の応力腐食割れ防止一高周波加熱 による残留応力の改善一, 矢田, 蕆林 (IHI).

4. 高温構造姴素におりる溶接継手のクリープ性能評 洒敒関する考察，佐藤，慗田（阪大），須清，松井，称， 清水, 佐藤 (川重).

5. 原子力ステンレス配管の自動溶接, 浜田，下山， 松山 (三菱重工).

の 5 件であり，原于力プララントに扔ける最新の溶接技 術の紹介亡理論解析であった。乙れら基調䍀演による問 題提起に対し，下記の諸氏から貫重なコメント，示唆に 富む意見の表明あるいは質問がなされた。

討論者：能戸(日本鋢管)，妹島（日立），松山（三菱 重工), 百合阔（新日鉄）, 大森（住友）, 須清 (川重), 藤原 (神銅)，豊田（神銅）

総括的コメントとして, 稲垣 (金材研) と小倉（横浜 国大）上り我国に拈ける原子力に関係する溶接技術の研 究の現状と本シンポジウムの位置つけ，更に今後の研労 の方向について貴重なコメントがあった。

基調報告は本誌 49 巻（1980）第 1 号に詳細な内容が揭 載されているので，以下シンポジゥムでの討論の内容を 簡単に紹介する。

*原稿受付 昭和56年 1 月 22 日

**正 員 石川息播庭董工釆(株)溶接研究所 Member, Weldiug Research Institute Ishikawajima-Harima Heavy Industries Co., Ltd.

\section{1. 原子力用機器への肉盛溶接法}

原子炉圧力容器内面の耐食合金の肉盛溶接および表面 硬化肉盛溶接の現状之問題点化ついて，竹中（東芝）か 基調報告を行った.

能戸 (日本鋼管) は，(1) 帶状電極 SAW に上る肉盛 溶接部を焼なました場合に発生する Under-clad Cracking に関連して，ビード幅がある值以上になると，母材 に対する熱影響は一定になるので，一般に使われている $\mathrm{Joule} / \mathrm{cm}$ よりも, その值を肉盛幅で割った绋, 又は 1 層肉盛厚さで比較するると, (2)暴材溶接における熟膨脹 を緩和するために，インコネルが使用されるが，日本鋼 管では,クラッド鋼の継手溶接及びフランジ面等の肉盛 溶按でプラズマホットワイヤ法を使用しており，ての方 法がインコネルの肉盛に適しているととを述べた。

妹島（日立）は，(1) SA533 ゃ SA508 鎝化 309 又は 309L ステンレス鋼を肉盛りした後，後熱処理する場合， 境界部が脆化するので熱処理温度と時問を制限すること

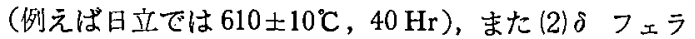

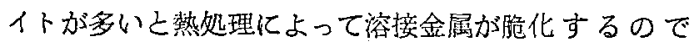
フェライト疽を制限すること，(3) 309 (Mo) では Cr 量 を24\%以上にすると勒性が低下するが，規格は23〜25\% となっていること，更に(4) 母材加らの C 移行むあるの で，とれらの値を制限するととを提案し，他社の実状を 尋视た.

松山（三菱重工）は，Under-clad Cracking の防止に 関連して原子哣容器の広巾バンド肉盛法が今後どのよう に展開して行くかという切実な問題を提起した。

\section{2. オーステナイト系ステンレス鎡の多層円周 突合せ溶接への水冷法の適用とその残留応 力}

管内婊面を水冷しながら溶接し，溶接継手部の残留応 力分布の測定を行い，その理諭解析を行った，溶接部内 表面での残留応力は, 空冷法では引張応力であるが, 水 


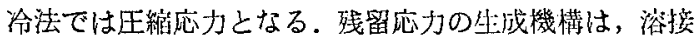
㨍の板厚方向の温度分布から説明でき, 内表面の鼬度上

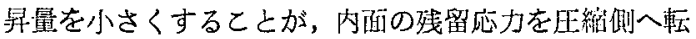
じさせるのに有効であると中言（阪大）は迹べた。

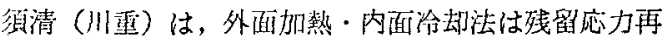
配分与法として有効であるが，溶接時，過度段階を利用 しているので，笑朋上の制限，例えば，適用板厚の上・ 下限があることを指摘した。

百合沭（新目鉄）は，円椆浴接の残留応力問題を通常 の FEM で解析する境合，辰時閉の計算となるが，本解 析打法では，ある程度玨確な応力値や变形量を比較的短

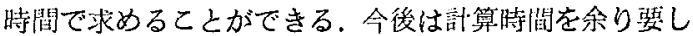
ない簡易な方法による研究が必留があり，その方法とし $\tau$, Rayleigh-Ritz 1 次元解析法之 Rybicki 等の多㬝溶 接を 2 パスに単純化する方泣で解く，2つの方问がある ことを述べた。

大森 (住金) は，石掂や天然ガス輸送用の大径ライン パイプにおいて，溶接部の㤂力閶食割れが問題となり， この防止泣として住金では残留応力の低減や压維応力化 を陚みた，しかし，これらのパイプラインは常時离い稼 動応力（公称降伏点の80\%）が働いているため割れを防 止できなかった、このような経験に基づき，本基調報告 の水冷法は材質改善効果によるの加總残留応力の生成 によるのか尋ねた，そして材質が改善されてない埸合は 音臽荷応力の下で応力倠食割れが発生するととを指摘し た.

\section{3.ステンレス鋼管の応力腐食割れの防止一高 周波加熱による残留応力の改善—}

発電用原子力プラントの配管系の溶接継手に応力閣食 割れが発生して以来，多くの防止対策が検討され実施さ れている，その一つに管内面を水冷しはがら外部から高

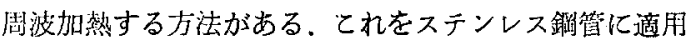
することによって管内面側に高い残留応力を与えること ができたてとを凧林（IHI）怙報告した。

大㷊（住金）は，前述と同様の見解に基づき；応力閻 食割れを防止するのに残留応力のみの改善（压纙化）で は不十分であるととを指推し，原子力配管での実績を尋 ねた．討論者の指摘のとおりであるが，一般に，奏機の 配管では降伏点の80\%といった高負荷応力はなく，基調 郝告者の方法では降伏点の80\%近い正縮の残留応力が得 られておりままた約 2 年間の奏績があるとの返答があっ た.

藤原（神鐳）は，高周波加熱による残留応力の改善は 稼動中のプランに適用できる有効な力法であるが; 割れ

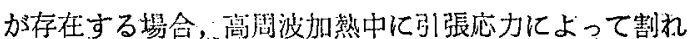
が進展する可能性と，逆に完了後は先端に高い正綃応力 が生じることを指摘した。

松山（三菱重工）は；内面の椧却条件，问䦌波コイル の設埧等による温度幻配の差違など，奏工等の信賴性の 問題を提题した。

\section{4. 高温構造要素における溶接継手のクリープ 性能評価に関する考察}

母材と溶接金属のクリープ特性の相違が溶接継手のク リープ奖能におよばす影篦について, Hastelloy X の溶 接継手の类験データに基づいて考察を行い，雨者のクリ ープデータから継手クリープ性能を評価する手法及び溶

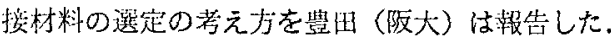

豐田（神鐡）は，(1)笑際の継手では，多䩜応力状態に おける变北の拘束，継手の溶接金属と全溶着金属との特 性の差，あるいは巽方性等を考慮する必要があり，また 試験片はてれらを忠实に模擬していることが望ましいと と，(2) 基調報告で, ASME Code Case N-47 の非弾性 ひずみの制限規定に触れているが，これは実験䇪データ のないような長時間での延性低下に対する考虑から設け られているととをコメントした。

\section{5. 原子カステンレス配管の自動溶接}

PWR 型原子力発電プラントの一次严配管士事で使用 する自動浴接施工法の考え方之，高品質かつ高能率の拖 工を行うための三蔆重工で発開した自動溶接法について 浜田（三菱重工）は武告した。

樭清（川重）は，(1)全姿勢自動 2 電極 TIG 溶接装血 について，能率面から2電極を採用しているが，㹨開先 とし，アークにようて開先壁を直接的に溶融させない偏

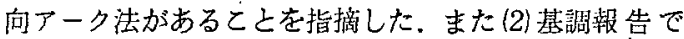
はステンレス鋳鋼について述べているが，他の鋼種への 適用が期待されるととを迅べた。

能戸（日本䥛管）は，乙の種の管の溶接においては良 好な寒波ビードを得るととが重要であり，その一つの方 法として管の旁側から寒波ビードの生成を光の鹏るさに よって檢出しそそれをフィードバックする方法度述心゙ t.

小山（日立）は，(1) 基調報告で, TIG Weld は一般に 作業能率が悪い（例えば溶接速度で $320 \sim 650 \mathrm{~mm} / \mathrm{min}$ ) と報告された点について，米国ダイメトリック社が 1400 $\mathrm{mm} / \mathrm{min}$ のデータを出しているとと, (2)一般に, ステン レス鋼の配管を全姿勢で溶接する場合，酸化しやすく， 酸化防止と酸化物除去法が問題であるととを述へた。 


\section{6. 総括的コメント}

小倉（横浜国大）は, 総括コメントとして, 本シンポ ジゥムでは残留灾力を扱った報告が多かったが，残留応 力以外の負荷による応力や塑性变形古考慮する必要があ ることを述へた。 なお，原子力圧力容器に関しては JPVRC においても調查検討がなされており，その成果 仙利用する価值があり，また本シンポジウムの成果を実 際の原子力プラントの溶接に生かされることを希望し た.

稲垣（金材研）は次のような詳絧な゙コントを行っ た.

今回の基調報告は，主として柽水炉関係の肉盛溶接施 工法及び配管系の溶接揓工法が取扱われ，また宿温ガス 炣関係の溶接継手のクリープ酸断特性が取扱われた。问 速炉関係はこれらと関係は媣いが，直接取扱われていな い.

（1）肉盛溶接施工法に関しては，近年各種の施工法が 開発実用化されており，従来の帯状電極サブマージアー ク溶接のほか, 日本製鋼, 神戸製鋼, 川崎製鉄などで浅 い溶込みで希积率を小さくすることができるエレクトロ スラグ方式を低融点フラックスや磁場制御などにより寒 現している，また三菱電機のソフトプラズマ法や住友金 属の大電流 TIG 溶接法などあ開発され実用されつつあ る、これらの一部は今回竹中らにより紹介されている が,なおクラッド鋼関媇の一連の JIS などが日本高圧力 技術協会.(HPI) クラッド委員会（委員長稲垣）等の活 動で下記のように作成されているので参㫴にされたい。

JIS G0601-1977「クラッド鋼の嫣験万法」

JIS G3601-1977「ステンレスクラッド鍓」

JIS G3602-1980「ニッケル及びニッケル合食クラ゙ッ ト鈄」

JIS G3603-1980「チタンクラッド鎡」

JIS G3604-1980「銅及び銅合金クラッド鋼」

HPIS E-105-1980「ステンレスクラッド鋼の施工基準 これらの規格におけるクラッド鋼の種類としては，肉 盛，压延，爆着あるいはこれらの製造法の二つ以上の組 合せを対象としている．また，原子炉用肉盛ステンレス クラッド鋼の共同研究については，日本溶接協会原子力 研究委員会で既任昭和 43 年度科学技術庁委託研究として 害施しており，その成果の要約が下記に揭㦲されてい る.

榴垣, 高压力, Vol. 8, No. 5 (1970) p. 2102-2113.

(2) オーステナイト系ステンレス鋼配管の溶接施工法 については, 軽水炉関係では高温水中の粒界応力腐食割 れ（粒界 SCC）が問題となり，この防止対策として溶接
中に管内面を水冷してその部分を圧綃残留心力に転換さ せる方法や溶接後管内を水冷しながら管外からの高周波 加熱によって管内面の残留応力を圧綃に転換させる万法 が今回派告された。售速炻関係では，オーステナイト系 ステンレス踻が主体で，その配管系の工場溶接及び現地 溶接, 補修溶接の自動化・無人化, 管一管板の突合せ㴼 崀, 溶接部の非破壊試験力法, 浴按法の迩択, 特に電子 ビーム溶接の適用などが問題になり，日本浴接協会原子 力研究委員会では動燃事業団の委䚶で, 三菱重下, 日立 製作, 石播, 東芝, 富士電機, 川重等の㙝力に上り高速 炉を対象にした一連の共同調查・研究を, 下記のように 実㨢している。

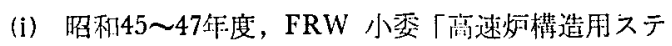
ンレス鋼の溶接脑厂红関する研究」

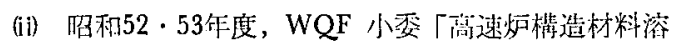
掞部の品旂評洒に関する調查」

(iii) 炤和51〜54年度, PFW-B 小委「ナトリウム配管 補修溶接法武験研究」

(iv) 昭利154年度以降，FWP 小霍「亶速炉用溶接施工。 法の確、江関する研忨」

これらの調查・研究成果の幾らかは，既に公表されて いる.

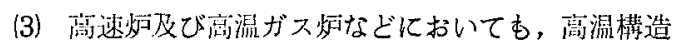
設計が要求され, ASME Code Case N-47（旧1592）を ベースに檑々検测されており，浴揬總手のクリープ破断 強度のみならず，非弾性ひずみ例限規定によりクリープ 伸びを䙺定する必要がある．とれらの浴接継手のクリー プ特性は目材のそれ之同等に確保することが一般に困難 であり，継手笛軸クリープ特性と内圧クリープ特性は力 学们及び材質们要因により䒽者の相違加見られ，また狭 開先アーク淮接や電子ビーム浴揬による継手のクリープ 特性など試験・研乱すべき課題が多い，乙れらの課題に 刘して, 佐藤, 須清らの浴接継手のクリープ性能評価に 関する考察は極めて興味媣い教告であり，溶接継手のク リープ破断性能を舟材のそれと同等にするための溶揬金 属の許容選択範围の提案に対して，ステンレス鍋等の各 㮔溶接法, 溶接材料, 溶接条件に上る継手の長時開クリ ープ試験を行い，具体拊なクリープデータによる実証が 必要であると考える。

終りに，全体の時䦭の制約があったにあかかわらず， 活発な討論によって多くの成果を得たてとに対し，で協 力戴いた関係者各位に感謝の意を表します。また，ての シンポジゥムの講演上討論が, 今後の原子カプラントの 溶接技術の向上に役立っていくことを期待する次第で す. 